Quim. Nova, Vol. 35, No. 7, 1318-1324, 2012

\title{
INVESTIGAÇÃO ELETROQUÍMICA E CALORIMÉTRICA DA INTERAÇÃO DE NOVOS AGENTES ANTITUMORAIS BISCATIÔNICOS COM DNA
}

\author{
Láuris Lucia da Silva, Claudio Luis Donnici* e Júlio César Dias Lopes \\ Departamento de Química, Instituto de Ciências Exatas, Universidade Federal de Minas Gerais, Av. Antônio Carlos, 6627, 31270 - \\ 901 Belo Horizonte - MG, Brasil \\ Marília Oliveira Fonseca Goulart, Fabiane Caxico de Abreu e Francine Santos de Paula \\ Instituto de Química e Biotecnologia, Universidade Federal de Alagoas, Campus A. C. Simões, Tabuleiro do Martins, 57072-970 \\ Maceió - AL, Brasil \\ Carlos E. Salas Bravo e Marcelo Matos Santoro \\ Departamento de Bioquímica e Imunologia, Universidade Federal de Minas Gerais, Av. Antônio Carlos, 6627, $31270-901$ Belo \\ Horizonte - MG, Brasil \\ Ângelo Márcio Leite Denadai \\ Centro Federal de Educação Tecnológica - Campus VII, Av. Amazonas 1193, 35183-006 Timóteo - MG, Brasil \\ Alexandre Martins Costa Santos \\ Departamento de Ciências Fisiológicas, Universidade Federal do Espírito Santo, Av. Marechal Campos 1468, 29043-900 Vitória \\ - ES, Brasil \\ Carlos Alberto Montanari \\ Instituto de Química de São Carlos, Universidade de São Paulo, CP 780, 13560-970 São Carlos - SP, Brasil
}

Recebido em 12/7/11; aceito em 24/2/12; publicado na web em 15/6/12

\begin{abstract}
ELECTROCHEMICAL AND CALORIMETRIC INVESTIGATION OF INTERACTION OF NOVEL BISCATIONIC ANTICANCER AGENTS WITH DNA. Biscationic amidines bind in the DNA minor groove and present biological activity against a range of infectious diseases. Two new biscationic compounds (bis- $\alpha, \omega-S$-thioureido, amino and sulfide analogues) were synthesized in good yields and fully characterized, and their interaction with DNA was also investigated. Isothermal titration calorimetry (ITC) was used to measure the thermodynamic properties of binding interactions between DNA and these ligands. A double stranded calf thymus DNA immobilized on an electrode surface was used to study the possible DNA-interacting abilities of these compounds towards $d s$ DNA in situ. A remarkable interaction of these compounds with DNA was demonstrated and their potential application as anticancer agents was furthered.
\end{abstract}

Keywords: biscationic compounds and interaction with DNA; isothermal titration calorimetry; electrochemical biosensor.

\section{INTRODUÇÃO}

O câncer é uma das doenças que mais causam temor na sociedade, por ter se tornado estigma de mortalidade e dor. ${ }^{1-3} \mathrm{Na}$ verdade, a palavra câncer refere-se ao termo neoplasia, especificamente aos tumores malignos, doença caracterizada pelo crescimento descontrolado de células transformadas; ${ }^{1} \mathrm{o}$ termo câncer é utilizado genericamente para representar um conjunto de mais de 100 doenças. ${ }^{1,2}$ Na verdade, quase todos os organismos multicelulares podem ser afetados pelo câncer, inclusive lesões cancerosas foram encontradas em fósseis de dinossauros e em múmias do Egito Antigo., ${ }^{4,5}$

Segundo a Organização Mundial da Saúde (OMS), o câncer é a segunda maior causa de mortalidade em todo mundo, atrás apenas das doenças de origem cardiovascular. ${ }^{6}$ Em 2008, a Agência Internacional para Pesquisa em Câncer (IARC/OMS) estimou que ocorreram 12,4 milhões de casos novos e 7,6 milhões de óbitos por câncer no mundo, e a OMS prevê que 84 milhões de pessoas devem morrer de câncer entre 2005 e 2015. ${ }^{7}$ Cerca de 1,5 milhão de casos de câncer são diagnosticados anualmente só nos EUA, e os médicos e pesquisadores do país estão engajados numa "guerra contra o câncer". ${ }^{6,7}$

No Brasil, o câncer apresenta-se como a segunda maior causa de morte nos últimos anos; as estimativas do Instituto Nacional de Câncer (INCA) apontam que, até o final de 2008, ocorreram mais de 470 mil novos casos de câncer, número maior do que o de pessoas

*e-mail: cdonnici@terra.com.br infectadas pelo vírus da AIDS nos últimos 25 anos, por exemplo. As estimativas para 2010 são válidas, também, para 2011 e apontam a ocorrência de 489.270 novos casos de câncer. Os tipos mais incidentes de câncer, à exceção do câncer de pele do tipo não melanoma, serão os de próstata e de pulmão, no sexo masculino, e os de mama e colo do útero, no sexo feminino. ${ }^{1,8}$

Embora nenhum medicamento ou tratamento definitivo contra o câncer tenha ainda sido encontrado, tem-se obtido grande progresso na compreensão das causas do câncer, no desenvolvimento de tratamentos efetivos e de novos quimioterápicos, na área de Medicina Oncológica. ${ }^{9} \mathrm{O}$ tratamento do câncer varia de acordo com o tipo e a gravidade da doença, podendo ser usado cirurgia, radioterapia, quimioterapia ou, ainda, a combinação dessas técnicas. A quimioterapia antineoplásica ou antiblástica é o método (geralmente por via oral ou intravenosa) que utiliza compostos químicos (agentes quimioterápicos). O objetivo primário da quimioterapia é destruir as células neoplásicas, preservando as normais, porém a maioria dos agentes quimioterápicos atua de forma não específica, lesando tanto células malignas quanto normais, particularmente as células de rápido crescimento como as gastrointestinais, capilares e as do sistema imunológico. Isto explica a maior parte dos efeitos colaterais da quimioterapia: náuseas, perda de cabelo e suscetibilidade maior às infecções, ${ }^{9-11}$ todavia, o corpo recupera-se destes inconvenientes após o tratamento e o uso clínico desses fármacos exige que os benefícios sejam confrontados com a toxicidade, na procura de um índice terapêutico favorável. ${ }^{9,12}$ Foram descritos vários alvos de ação 


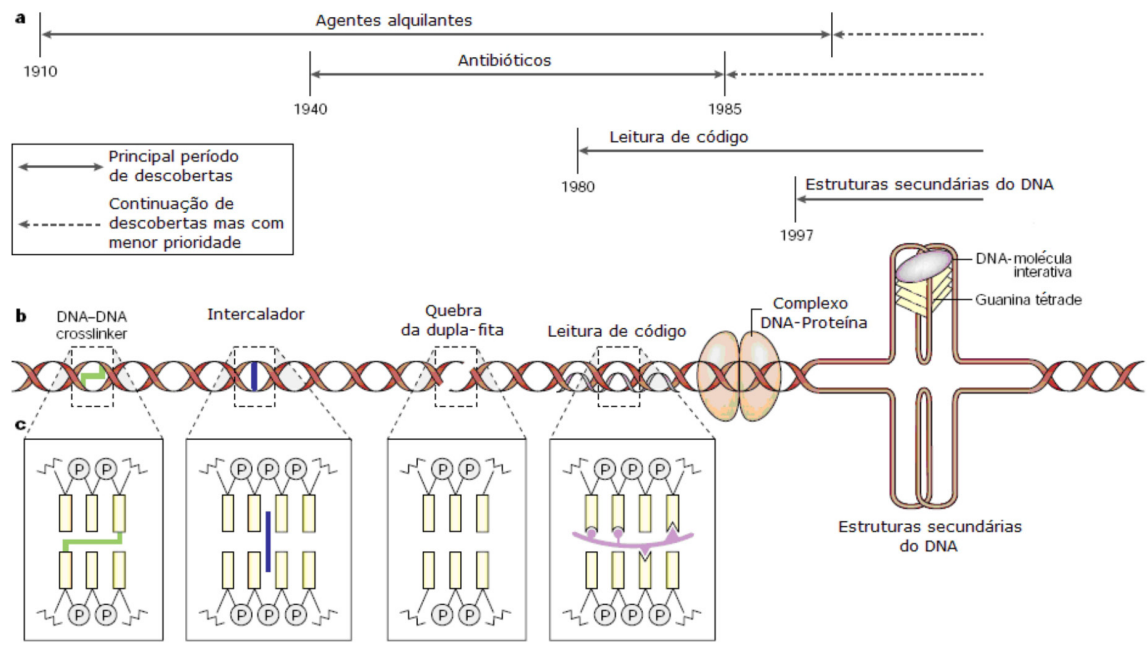

Figura 1. Classes de agentes DNA-interativos e suas interações moleculares com DNA. a) Linha do tempo para a descoberta e evolução de agentes DNA-interativos até o presente. b) Ilustração dos tipos de modificação que podem se formar no DNA, incluindo ligações cruzadas, intercalação, clivagem da fita do DNA e moléculas leitoras de códigos genéticos. A hélice do DNA é também mostrada associada com proteínas, como a topoisomerase II, e com estruturas secundárias do DNA (guanina-quádrupla). c) Detalhes dos modelos, mostrando os diferentes tipos de modificação do DNA. Adaptada da ref. 14

para os agentes antineoplásicos e, em muitos deles, o mecanismo de ação está relacionado ao DNA (Figura 1). 3.12-15

O DNA continua sendo considerado um alvo importante na busca de agentes quimioterápicos, desde que compostos mais seletivos e menos tóxicos vêm sendo preparados e investigados visando os receptores moleculares, como moléculas DNA-reativas. ${ }^{3,15}$ Dentre os agentes antineoplásicos que apresentam interação com o DNA (Figura 1), destacam-se os agentes alquilantes, principalmente as mostardas nitrogenadas, como a mecloretamina (Mustargen ${ }^{\circledR}$ ) (Figura 2) que são antineoplásicos pioneiros,${ }^{16}$ os mais estudados e ainda usados na atualidade, como os fármacos Melphalan ${ }^{\circledR}$, Bendamustina (Ribomustin ${ }^{\circledR}$, Treanda $^{\circledR}$ ), a ciclofosfamida (ou Cytofosfan, Endoxan ${ }^{\circledR}$, Cytoxan $^{\circledR}$, Neosar $^{\circledR}$, Procytox $^{\circledR}$, Revimmune $^{\circledR}$ ) e o clorambucil (Leukeran ${ }^{\circledR}$ ), também derivados da mecloretamina. ${ }^{3,8,14,15}$<smiles>CC(C)(C)N(CCCl)CCCl</smiles><smiles>O=P1(N(CCCl)CCCl)NCCCO1</smiles><smiles>CC(C)(C)c1ccc(N(CCCl)CCCl)cc1</smiles>

Ciclofosfamida<smiles>Cn1c(CCCC(=O)O)nc2cc(N(CCCl)CCCl)ccc21</smiles>

Bendamustina

Figura 2. Estruturas de mostardas nitrogenadas usadas como agentes quimioterápicos antineoplásicos

É digno de nota que estes agentes serviram de compostos-modelo para o planejamento racional de análogos com potencial atividade antineoplásica, como realizado por Cohen e colaboradores e por Stark e Meadows, ${ }^{17,18}$ que estudaram derivados mistos espermidina-clorambucil (Figura 1Sa, material suplementar). Prakash e colaboradores também estudaram derivados mistos intercalantes-clorambucil
(Figura 1Sb, material suplementar), ${ }^{19}$ todos com alta potencialidade como agentes antineoplásicos. Pode-se notar que nestes casos ocorre o efeito sinérgico da parte alquilante $\left(\mathrm{N}-\mathrm{CH}_{2}-\mathrm{CH}_{2} \mathrm{Cl}\right)$ com a outra parte adicionada: no primeiro caso (Figura $1 \mathrm{Sa}$ ) os grupos amino da parte espermidínica estão protonados e geram interações eletrostáticas com o DNA; no segundo caso (Figura 1Sb) os anéis heteroaromáticos devem adentrar na fenda do DNA por intercalação, gerando interações lipofílicas secundárias, que acentuam a atividade farmacológica potencial. Cabe ressaltar que o DNA apresenta dois alvos principais para interação com outras moléculas: a fenda maior e a fenda menor. Enquanto a fenda maior possui maior chance de interação com moléculas proteicas através de ligações de hidrogênio ou interações hidrofóbicas, a fenda menor (10 A), com a metade da largura da fenda maior, geralmente pode interagir com moléculas de menor tamanho (<1000 Da). Os ligantes da fenda menor podem inibir a condensação de cromatina e alterar a expressão gênica, modificando o ciclo celular. Vários destes ligantes são derivados amidínicos que reconhecem sequências A/T na fenda menor (berenil e neptrosina (Figura 2S, material suplementar), DAPI, estilbamidina, pentamidina, distamicina e outras). Algumas poliamidas e diamidinas sintéticas que se ligam à fenda menor interferem com a interação de proteínas em regiões ricas em sequências A/T do DNA satelital. Alguns destes ligantes se ligam de modo reversível ao DNA, enquanto outros induzem alterações irreversíveis (como, por exemplo, alquilação do N3 da adenina). ${ }^{20}$ Destaca-se que podem surgir fenômenos de resistência ao tratamento de neoplasias com uso de agentes antineoplásicos comuns na clínica médica oncológica e que são ligantes da fenda maior, como a cisplatina; para atenuar esta resistência pode-se então usar um segundo tratamento, que pode ser feito com ligantes na fenda menor. ${ }^{21}$

Estudos têm mostrado que alguns fármacos, como compostos biscatiônicos conhecidos como bis-amidinas, são conformacionalmente côncavos e apresentam conformações, ditas iso-hélicas, com a complementaridade adequada para a ocorrência de interações (isohelicity concept) e interagem com a forma convexa do DNA, ${ }^{22}$ levando a interações seletivas, possibilitando o desenvolvimento de fármacos de alta potência. Incluem-se nessa classe de ligantes à fenda menor do DNA algumas moléculas pequenas, que apresentam seletividade por regiões A/T, como o berenil e o Hoechst 33258 (Figura 2S, material suplementar) ${ }^{23-25}$ Existem diversos estudos sobre a interação com o DNA e atividades biológicas de fármacos, como a distamicina e netropsina (Figura 2S, material suplementar). A netropsina foi o 
primeiro composto identificado como ligante da fenda menor (minor groove binders, MGBs) e sua energia de interação com o DNA é da ordem de 10-12 $\mathrm{Kcal} \mathrm{mol}^{-1}$. Apresenta uma elevada especificidade na interação com o DNA, em especial na ligação com o B-DNA, a conformação mais comum do DNA e que apresenta a hélice mais alongada. ${ }^{24,26,27}$

Cabe ressaltar que moléculas que apresentam interações específicas com a fenda menor do DNA têm despertado interesse como potenciais agentes terapêuticos em uma variedade de doenças humanas, além de câncer, como se pode verificar em artigos de revisão importantes. ${ }^{14,20-22,25,26}$ Porém, verifica-se na literatura que ainda não foram estudados agentes antineoplásicos mistos do tipo alquilantes-bisamidinas, que apresentam interação eletrostática forte e específica com o DNA, sem o efeito colateral da ação não seletiva dos agentes alquilantes. Este artigo focou especificamente da investigação da interação com o DNA de grupos funcionais dicatiônicos (S-tioureídos) análogos à amidina, derivados que foram planejados com base em modificações estruturais de antitumorais conhecidos e usados clinicamente, como a mecloretamina, visando gerar novos fármacos antineoplásicos mais potentes e menos tóxicos.

\section{PARTE EXPERIMENTAL}

Os espectros de absorção na região do infravermelho foram obtidos num espectrômetro interferométrico Mattson Instruments Galaxy 3000, na faixa de 400 a $4000 \mathrm{~cm}^{-1}$. Os espectros em filme líquido foram obtidos utilizando-se janelas de $\mathrm{NaCl}$ ou celas de $\mathrm{NaCl}$ de 0,025 $\mathrm{mm}$ de espessura e para sólidos os espectros foram obtidos na forma de pastilhas de $\mathrm{KBr}$.

A determinação dos espectros de ressonância magnética nuclear de hidrogênio ( $\mathrm{RMN}$ de ${ }^{1} \mathrm{H}$ ) e de carbono-13 (RMN de ${ }^{13} \mathrm{C}$ ) foi realizada nos espectrofotômetros Bruker 200 e $400 \mathrm{MHz}$. Os deslocamentos químicos são relatados em partes por milhão $(\delta)$ em relação ao tetrametilsilano (TMS), usado como padrão interno. Os solventes utilizados foram água deuterada, deuteroclorofórmio $\left(\mathrm{CDCl}_{3}\right)$ e o dimetilsulfóxido (DMSO). Os pontos de fusão foram determinados em aparelho Fisher-Jons, sem correção.

As análises por espectrometria de massas (EM) foram realizadas em cromatógrafo gasoso Shimadzu GC-17-A acoplado a espectrômetro de massas Shimadzu GCMS-QP5050A, do Departamento de Química da UFMG; coluna DB-1 (J \& W Scientific), comprimento $30 \mathrm{~m}$, DI: 0,25 mm; espessura do filme $0,25 \mu \mathrm{m}$, série $7513112 \mathrm{~S}$. Temperaturas de injetor e detector: 250 e $280{ }^{\circ} \mathrm{C}$, respectivamente; temperatura inicial $80^{\circ} \mathrm{C}$ por 5 min e aquecimento de $10^{\circ} \mathrm{C} \mathrm{min}{ }^{-1}$ até $250^{\circ} \mathrm{C}$; impacto de $70 \mathrm{eV}$.

\section{Procedimentos para preparação dos compostos}

Os compostos $\mathbf{2}$ e $\mathbf{3}$ foram preparados a partir dos di-haletos correspondentes $\mathbf{1}$ (preparado como descrito a seguir) (Figura 3) e mecloretamina (obtida comercialmente através da Sigma-Aldrich ${ }^{\circledR}$ ). Todos os compostos foram caracterizados em alta pureza e analisados pelas técnicas espectrométricas usuais.

\section{1,7-di-cloro-4-tia-heptano $(1)^{28}$}

A um balão de fundo redondo, sob agitação magnética à temperatura ambiente, adicionou-se 1-bromo-3-cloropropano (20,0 g; $127,0 \mathrm{mmol})$ e etanol $(110 \mathrm{~mL})$. A esta solução, adicionou-se uma solução de sulfeto de sódio nona-hidratado (18,3 g; 76,0 mmol em 40 $\mathrm{mL}$ de água), adaptou-se um condensador de refluxo e a mistura foi aquecida em banho de óleo, sob agitação magnética e aquecimento a $60{ }^{\circ} \mathrm{C}$, por $5 \mathrm{~h}$. Após resfriamento, o solvente foi removido sob pressão reduzida em evaporador rotativo e realizada a extração desse
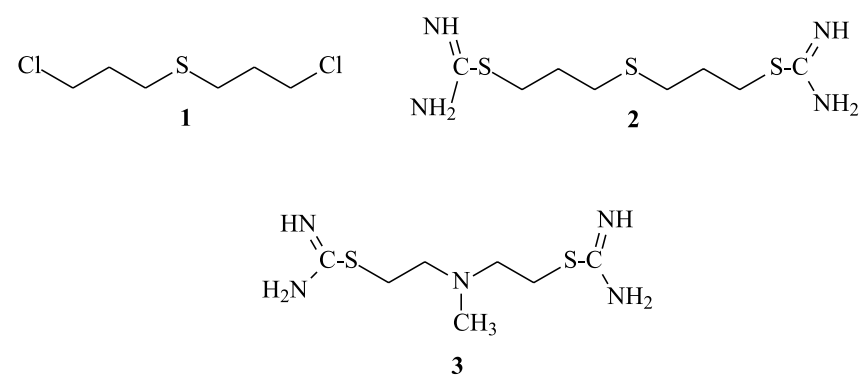

Figura 3. Estruturas dos compostos 1,7-di-cloro-4-tia-heptano (1), 1,7-bis-(2-isotioureído)-4-tia-heptano (2) e N-metil-1,5-bis-(2-isotioureído)-3-aza-pentano (3)

produto com clorofórmio ( 3 x 50,0 mL) e secagem com sulfato de sódio anidro obtendo-se, após filtração e evaporação do solvente, 8,5 $\mathrm{g}$ de um líquido amarelo; os dados do espectro de massas revelaram que se tratava de uma mistura de cerca de $10 \%$ (análise das alturas relativas e dos picos referentes a ${ }^{81} \mathrm{Br}^{37} \mathrm{Cl} /{ }^{79} \mathrm{Br}{ }^{35} \mathrm{Cl}$ ) de 1-bromo-7-cloro-4-tia-heptano (1a) e $90 \%$ (análise das alturas relativas e dos picos referentes a ${ }^{37} \mathrm{Cl}^{37} \mathrm{Cl} /{ }^{35} \mathrm{Cl}^{35} \mathrm{Cl}$ ) de 1,7-dicloro-4-tia-heptano (1). Após destilação sob pressão reduzida $\left(108-109{ }^{\circ} \mathrm{C} / 3 \mathrm{~mm}\right.$ de $\mathrm{Hg}$ ), obteve-se 7,65 g de 1 (41 mmol; 65\% de rendimento; 2:1 $\mathrm{mol} / \mathrm{mol}$ dihaleto-sulfeto de sódio, respectivamente). IV (filme $\mathrm{NaCl}, \mathrm{cm}^{-1}$ ) $v_{\max } 2930,1440,1270,840,770 ; \mathrm{RMN}$ de ${ }^{1} \mathrm{H}\left(200 \mathrm{MHz}, \mathrm{CDCl}_{3}\right)$ $\delta 3,78(\mathrm{t}, 4 \mathrm{H}, J=6,8 \mathrm{~Hz}) ; 3,51(\mathrm{t}, 4 \mathrm{H}, J=6,8 \mathrm{~Hz}) ; 2,62(\mathrm{~m}, 4 \mathrm{H}, J=$ $6,8 \mathrm{~Hz})$; RMN de ${ }^{13} \mathrm{C}\left(50 \mathrm{MHz}, \mathrm{CDCl}_{3}\right) \delta 43,3$ (C-1); 32,1 (C-3); 28,7 (C-2); EM m/z: [M+]: $186\left(8,0 \%,{ }^{35} \mathrm{Cl}^{35} \mathrm{Cl}\right) / 188\left(5,3 \%,{ }^{37} \mathrm{Cl}^{35} \mathrm{Cl}\right)$, $\left[\mathrm{M}^{+}-\mathrm{C}_{3} \mathrm{H}_{7} \mathrm{ClS}\right]: 110\left(25 \%,{ }^{35} \mathrm{Cl}\right) / 112\left(8,3 \% ;{ }^{37} \mathrm{Cl}\right)$.

\section{1,7-bis-(2-isotioureído)-4-tia-heptano (2)}

A um balão de fundo redondo, adicionou-se 1,7-di-halo-tio-heptano 1 (2,00 g; $11 \mathrm{mmol})$, etanol (15 mL) e tiouréia (1,60 g; $22 \mathrm{mmol})$, adaptou-se um condensador de refluxo fechado com tubo dessecador contendo cloreto de cálcio. Essa mistura foi aquecida em banho de óleo e mantida sob agitação magnética e aquecimento a $60^{\circ} \mathrm{C}$ por 24 h. Após resfriamento, com um bastão de vidro, fez-se uma pequena fricção no fundo do balão, para iniciar a cristalização de tiouréia residual que, usualmente, se precipita por completo, após 15 min no freezer. Formaram-se, assim, duas fases: uma sólida e uma líquida, ambas analisadas por CCD (eluente metanol a $40 \%$ (v/v) em acetato de etila, e revelador iodo; o produto desejado estava na fase líquida. Em seguida, fez-se uma filtração, o líquido foi levado ao evaporador rotatório sob pressão reduzida para retirada da maior parte do solvente e, após cristalização no freezer por uma noite, filtração e secagem sob baixa pressão, obteve-se um sólido rosa 2 (2,87 g, 8,5 mmol; 79\% de rendimento). P.F. $=155,0-157,0^{\circ} \mathrm{C}$. IV (filme KBr, $\mathrm{cm}^{-1}$ ) $v_{\max } 3000$, 1630, 1530, 1400, 1250; RMN de ${ }^{1} \mathrm{H}\left(200 \mathrm{MHz}, \mathrm{D}_{2} \mathrm{O}\right): \delta 8,4$ (s, NH, $8 \mathrm{H}) ; 3,1(\mathrm{t}, 4 \mathrm{H}, J=7,0 \mathrm{~Hz}) ; 2,6(\mathrm{t}, 4 \mathrm{H}, J=6,4 \mathrm{~Hz}) ; 1,9(\mathrm{~m}, 4 \mathrm{H}, J=$ $6,7 \mathrm{~Hz})$; RMN de ${ }^{13} \mathrm{C}\left(50 \mathrm{MHz}, \mathrm{D}_{2} \mathrm{O}\right): \delta 171,6(\mathrm{C}-1$ ') $; 29,8(\mathrm{C}-1)$; 29,5 (C-3); 27,9 (C-2).

\section{N-metil-1,5-bis-(2-isotioureído)-3-aza-pentano $(3)^{29}$}

$\mathrm{O}$ composto $\mathbf{3}$ foi sintetizado empregando-se o mesmo procedimento descrito para a síntese de 2 . Fez-se reagir mecloretamina (0,5 g; 2,6 mmol), tiouréia $(0,4 \mathrm{~g} ; 5,2 \mathrm{mmol})$ em etanol $(40 \mathrm{~mL})$. Houve precipitação de um sólido amarelado cristalino, que foi filtrado sob baixa pressão e secado no dessecador, obtendo-se 0,72 $\mathrm{g}$ de 3 (2,0 mmol; $80 \%$ de rendimento). P.F. $=166,0-168,0{ }^{\circ} \mathrm{C}$. IV (filme $\left.\mathrm{KBr}, \mathrm{cm}^{-1}\right) v_{\text {max }} 3000,1630,1520,1420,1250 ; 910 ; \mathrm{RMN}$ de ${ }^{1} \mathrm{H}$ (400 MHz, DMSO): $\delta$ 9,4 (s, NH, 8H); 3,7 (s, 4H); 3,4 (s, 4H); 2,8 (s, 4H); RMN de ${ }^{13} \mathrm{C}$ (100 MHz, DMSO): $\delta$ 168,8 (C-1'); 53,5 (C-1); 40,1 (C-2 e C-2'). 


\section{Calorimetria diferencial de varredura (DSC)}

As análises por DSC foram realizadas no microcalorímetro VPDSC Microcal. Usou-se o programa Origin-DSC 5.0 (Microcal) para tratamento matemático dos dados. As soluções do DNA (dodecâmero d(CGCGAATTCGCG) do DNA (0,3 mM) (Oswel 2979) e dos respectivos ligantes foram preparadas em água desionizada em $\mathrm{pH} 7,0$, contendo $10 \mathrm{mM}$ de cacodilato de sódio, $5 \mathrm{mM}$ de $\mathrm{NaCl}$ e $0.1 \mathrm{mM}$ EDTA; a concentração final de DNA, medida espectroscopicamente, foi $0,33 \mathrm{mM}$.

As amostras foram degaseadas por $40 \mathrm{~min}$ em equipamento conectado a bomba de vácuo e, a seguir, introduzidas no microcalorímetro e adicionou-se $0,7 \mathrm{~mL}$ da solução a ser analisada na célula do DSC. Estas amostras foram, então, submetidas à varredura de temperatura, utilizando a solução tampão como referência, na faixa de temperatura de $25-100{ }^{\circ} \mathrm{C}$, com taxa de varredura $30,0 \pm 0,1{ }^{\circ} \mathrm{C} / \mathrm{h}$ e pressão de 25,0 $\pm 0,5$ psi. A solução tampão foi escaneada para obtenção da linha base e para posterior subtração da linha base das amostras.

\section{Titulação calorimétrica isotérmica (ITC - Isothermal Titration Calorimetry)}

As análises por ITC foram feitas a $22{ }^{\circ} \mathrm{C} \mathrm{em}$ aparato de microcalorimetria MycroCal VPITC (Microcal, Northampton, MA). Usou-se o programa Origin-DSC 5.0 (Microcal) para tratamento matemático dos dados. Foram titulados 1,5 mL de dodecâmero d(CGCGAATTCGCG) do DNA (0,3 mM) (Oswel 2979), rotação de 400 rpm e adição das amostras a serem analisadas nas concentrações de 2 a 3 mM (50 injeções de $5 \mu \mathrm{L}$ ). Estas soluções foram preparadas em água desionizada em pH 7,0, contendo $10 \mathrm{mM}$ de cacodilato e $5 \mathrm{mM}$ de $\mathrm{NaCl}$. O tempo de injeção foi 12 s e o tempo de decaimento ajustado em 4 min. Os picos produzidos durante a titulação foram convertidos em calor pela injeção e integração, a correção do volume da célula e concentração da amostra. Através da técnica de ITC podem-se obter diretamente os parâmetros de afinidade de interação $\left(\mathrm{K}_{\mathrm{B}}\right)$, entalpia $(\Delta \mathrm{H})$ e estequiometria (n) da interação entre as espécies em solução. A partir destas medidas iniciais obtêm-se dados de variações de energia de Gibbs $(\Delta \mathrm{G})$ e de entropia $(\Delta \mathrm{S})$, que podem ser determinadas através da equação $\Delta \mathrm{G}=-\mathrm{RT} \ln \mathrm{K}_{\mathrm{B}}=\Delta \mathrm{H}-\mathrm{T} \Delta \mathrm{S}(\mathrm{R}$ : constante dos gases e $\mathrm{T}$ : temperatura absoluta, K).

\section{Eletrodo modificado de DNA}

Os voltamogramas e os experimentos de voltametria cíclica foram realizados utilizando um potenciostato Autolab PGSTAT 20, em meio prótico (tampão acetato $\mathrm{pH} 4,5$ ), em sistema de três eletrodos: de carbono vítreo (BAS, diâmetro 3,0 mm) como eletrodo de trabalho; de platina, como auxiliar e como eletrodo de referência Ag/ $\mathrm{AgCl}, \mathrm{Cl}^{-}\left(0,1 \mathrm{~mol} \mathrm{~L}^{-1}\right)$, em um tubo capilar de Luggin com vycor na extremidade. A análise e o tratamento dos dados foram realizados a partir de gráficos obtidos nos experimentos e tratados com o auxílio do programa Origin 6.0.

Preparo do gel de DNA: o gel de $d s$ DNA (timo de terneiro) foi preparado pela dissolução de $18,75 \mathrm{mg}$ do mesmo em $1 \mathrm{~mL}$ de tampão acetato (pH 4,5) em um tubo eppendorf. O gel foi armazenado a $4{ }^{\circ} \mathrm{C}$ por $24 \mathrm{~h}$ para homogeneização e para evitar a degradação pelo calor.

Incorporaram-se, na superfície do eletrodo de trabalho, $50 \mu \mathrm{L}$ do gel de DNA, recobrindo toda a superfície do eletrodo de carbono vítreo. Após $24 \mathrm{~h}$ de secagem do gel, adicionaram-se $50 \mu \mathrm{L}$ da solução a ser analisada mais tampão $\mathrm{pH} 4,5$ (canalyte $=1 \mathrm{~g} \mathrm{~L}^{-1}$ ), por cima do gel seco, deixando-se secar por mais $24 \mathrm{~h}$. Esse eletrodo modificado foi então imerso na cela eletroquímica contendo $5 \mathrm{~mL}$ do tampão $\mathrm{pH} 4,5$, para realização de experimentos de voltametria de pulso diferencial (VPD), utilizado um potenciostato Autolab PGSTAT-30 da Echo Chemie acoplado a um computador operando com o programa GPES 4.9.

\section{RESULTADOS E DISCUSSÃO}

\section{Calorimetria diferencial de varredura (DSC)}

Com os derivados 1, 2 e $\mathbf{3}$ (Figura 3), obtidos por via sintética, utilizou-se primeiramente a técnica de calorimetria diferencial de varredura (DSC) como uma investigação preliminar da possível interação com o DNA e posterior aplicabilidade como agentes antitumorais. Estudou-se a interação dos compostos 1, 2 e 3 com o DNA e a capacidade calorífica dessa interação. Na Figura 4, estão representados os termogramas das interações dos compostos com o DNA, e seus respectivos Tm (temperatura na qual metade das moléculas DNA está $50 \%$ desenovelada, ou desnaturada, e 50\% nativa). Os três derivados apresentaram interações irreversíveis características com o DNA: o sistema DNA mais derivados amidínicos, bioisostéricos ao grupo S-tioureído apresentam transformações térmicas irreversíveis. Os compostos 1, 2 e 3 aumentaram o Tm do DNA (Figura 4), indicando a estabilização da forma enovelada do DNA. Dentre os três compostos estudados, o derivado di-haleto 1 foi o que apresentou maior interação com o DNA, dado o maior valor de Tm obtido.

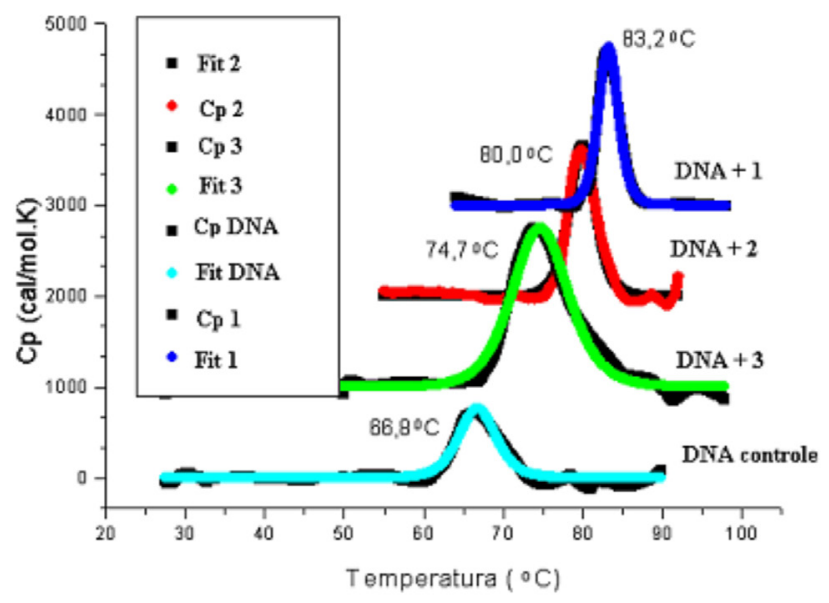

Figura 4. Termogramas do DNA e da interação dos compostos 1, 2 e $\mathbf{3}$ com o DNA; do lado esquerdo de cada termograma o respectivo Tm (temperatura na qual metade das moléculas se encontra $50 \%$ desenovelada e $50 \%$ nativa)

\section{Titulação calorimétrica isotérmica (ITC)}

A titulação calorimétrica isotérmica (ITC) é uma técnica utilizada para estudar as interações proteína-DNA, DNA-surfactante, antígeno-anticorpo, enzima-substrato e o efeito transcricional de pequenas moléculas reguladoras. ${ }^{30,31}$ É muito utilizada no estudo de processos por complexometria, tendo como fundamento a medida do fluxo de calor envolvido na reação. ${ }^{32,33}$ Efetua-se uma titulação microcalorimétrica para medir a extensão da interação (ou ligação) de uma molécula (componente A) que é adicionada em quantidades e concentrações definidas a outra molécula (componente B), medindo-se o calor gerado. ${ }^{31,34}$ É uma técnica em que a constante de ligação $(\mathrm{Kb})$, energia livre de ligação de Gibbs $(\Delta \mathrm{G})$, entalpia $(\Delta \mathrm{H})$ e entropia $(\Delta S)$ podem ser determinadas diretamente e com alta precisão, a partir de um único experimento. ITC tem encontrado ampla aplicação no estudo de sistemas biológicos, devido à caracterização termodinâmica completa. ${ }^{34,35}$ 
Os parâmetros termodinâmicos da ligação dos compostos amidínicos com o DNA foram investigados por meio da titulação calorimétrica isotérmica. Na Figura 3S (material suplementar) estão representados os gráficos dos estudos microcalorimétricos por ITC da interação entre $\mathbf{2}$ e $\mathbf{3}$ com o dodecâmero sintético do DNA d(CGCGAATTCGCG); os resultados dos estudos da interação de $\mathbf{1}$ com o DNA, todavia, não foram conclusivos. Cada pico associado ao calor de uma única injeção e os calores de injeção foram corrigidos pela subtração das diluições. Nos gráficos inferiores da Figura 3S (material suplementar), as injeções corrigidas foram analisadas juntamente com as taxas molares e, nos gráficos superiores, têm-se os dados experimentais dos calores de injeção. Algumas características importantes das amidinas estudadas foram obtidas a partir dos dados de ITC, assim como os parâmetros termodinâmicos da ligação da amidina-DNA. Os dois compostos estudados apresentavam grupos funcionais amidínicos, bioisostéricos ligados ao grupo S-tioureído; 2 é um derivado S-tioureído e o composto 3, análogo da mecloretamina, apresentou N-Me no lugar do átomo de enxofre. Os dois derivados biscatiônicos apresentaram uma interação exotérmica. O composto 3 apresentou estequiometria 1:1 para um sítio do DNA, o que evidencia a interação com uma fita do DNA, com alta constante de formação $\mathrm{K}_{\mathrm{B}}:(4,7 \pm 1,7) \times 10^{5}$. Os parâmetros termodinâmicos obtidos para esta interação foram: constantes de formação $\left(\mathrm{K}_{\mathrm{B}}\right)$ : $(4,7 \pm 1,7) \times 10^{5}$; entalpia $(\Delta \mathrm{H})$ : - $(1286 \pm 75) \mathrm{cal} \mathrm{mol}^{-1}$ e entropia $(\Delta \mathrm{S}): 21,6 \mathrm{cal} \mathrm{molK}^{-1}$. Entretanto, para o composto 2, os resultados foram muito dispersos e nota-se uma interação muito fraca (Figura 3S, material suplementar), no caso do composto $\mathbf{1}$, estes resultados foram ainda mais dispersos e inconclusivos. Comparativamente, pode-se concluir que a presença da parte N-Me, em 3, foi fundamental para a interação com o DNA. O outro derivado S-tioureído sulfeto 2 apresenta três grupos metilênicos entre os grupos S-tioureído, conferindo maior liberdade rotacional e certamente menor seletividade para interação com o DNA. Os resultados obtidos com esses compostos são compatíveis com o esperado para interação eletrostática de ligantes amínicos com DNA. ${ }^{36}$ Contudo, é necessário o uso de outra técnica para melhor avaliação da interação do composto 2 com o DNA.

A partir da análise dos termogramas da interação entre os compostos estudados e o DNA (Figura 4), nota-se que todos os compostos apresentaram transições típicas, porém, em nenhum dos casos testados observou-se reversibilidade do processo, mostrando assim que os sistemas DNA + compostos passam por uma transição térmica irreversível. Também se pode dizer que a adição de qualquer um dos compostos aumentou o Tm do DNA controle, podendo-se concluir-se que as moléculas-teste estabilizam a forma enovelada do DNA, como se pode observar no seguinte esquema:

(F)- fold - dobrada, enovelada ou estado ordenado

(U) - unfold - desdobrada, desenovelada ou estado desordenado

L - Ligante (compostos 1, 2 e 3)

$\mathrm{DNA}_{(\mathrm{F})} \rightarrow \mathrm{DNA}_{(\mathrm{U})}$ Transição de um estado ordenado para um desordenado

$\mathrm{DNA}_{(\mathrm{F})}+\mathrm{L} \rightarrow \mathrm{DNA}_{(\mathrm{F})}-$ L Aumento no Tm

$\mathrm{DNA}_{(\mathrm{U})}+\mathrm{L} \rightarrow \mathrm{DNA}_{(\mathrm{U})}-$ L Diminuição do Tm

Observa-se que o composto que interagiu melhor com o DNA, estabilizando melhor sua forma nativa (ordenada) foi o di-haleto $\mathbf{1}$, pois apresentou um maior $\Delta \mathrm{Tm}$ (diferença da temperatura de desenovelamento do DNA e da temperatura do desenovelamento do DNA com o composto em estudo) em comparação com as outras moléculas, destacando-se que o composto derivado da mecloretamina 3 foi o que apresentou maior interação entre os derivados biscatiônicos estudados. Adicionalmente, pode-se investigar o índice de cooperatividade da transição entre estados nativos e desenovelados do DNA e DNA + ligantes, pois este índice reflete qualitativamente a variação do $\Delta \mathrm{H}_{\mathrm{vH}}$ durante a transição do estado enovelado e desenovelado do DNA e $\mathrm{DNA}+$ ligante; quanto maior for o valor $\Delta \mathrm{T}(1 / 2 \mathrm{H})$, menor será o índice de cooperatividade. Analogamente, como esperado e observado na Tabela 1, o composto que associado ao DNA fez a transição térmica ficar mais cooperativa foi o di-haleto $\mathbf{1}$, seguido do derivado 3 .

Tabela 1. Dados dos valores de $\Delta \mathrm{Tm}$ e de $\Delta \mathrm{T}(1 / 2 \mathrm{H})$ obtidos dos termogramas da interação entre os compostos estudados e do DNA

\begin{tabular}{ccc}
\hline Moléculas & $\Delta \mathrm{Tm}$ & $\Delta \mathrm{T}(1 / 2 \mathrm{H})^{*}$ \\
\hline DNA & - & 1.8 \\
DNA + 1 & 16,4 & 0.8 \\
DNA + 2 & 5,8 & 1.0 \\
DNA + 3 & 7,9 & 2.0 \\
DNA + padrão & 6,6 & 0.5 \\
\hline
\end{tabular}

$* \Delta \mathrm{T}(1 / 2 \mathrm{H})=$ diferença de temperatura $\left({ }^{\circ} \mathrm{C}\right)$ na altura média do pico de transição do termograma.

A partir da análise dos valores de Tm e do índice de cooperatividade, conclui-se que o derivado $\mathbf{1}$ apresenta, termodinamicamente, o melhor perfil de ligação ao DNA. Devido ao fato do efeito entrópico ser dominante, provavelmente a força motriz da interação está associada ao efeito de dessolvatação do ligante e do DNA (ambos carregados) durante a interação. A variação de Tm observada (entre 7-13 ${ }^{\circ} \mathrm{C}$ ) indica que os complexos são formados com o DNA por interações fortes e provocam alterações na estrutura terciária do polímero, embora em grau menor, analogamente ao Berenil que é o composto utilizado como referência nesse estudo. ${ }^{23}$ De fato, estes dados de variação de Tm são similares ao esperado para forte interação eletrostática de ligantes biscatiônicos com DNA. ${ }^{37-40}$

\section{Estudo eletroquímico com eletrodo modificado de $d s$ DNA}

Em 1993, Millani e Mikkelsen introduziram o conceito de biossensor eletroquímico com DNA hibridizado. ${ }^{41}$ Atualmente, os eletrodos modificados com DNA, que podem ser até chamados em alguns casos de biossensores de DNA, têm sido utilizados em diversas aplicações, tais como, testes de água, comida, solo, amostras de plantas com analitos (carcinogênicos e poluentes mutagênicos)..$^{42,43}$ Os biossensores aplicáveis no reconhecimento de ácidos nucleicos foram desenvolvidos com o objetivo de se efetuar testes rápidos, simples e de baixo custo para diagnóstico preciso de agentes infecciosos em vários ambientes, para monitorar diretamente sequências de hibridizações específicas, ou por intercaladores que complexam as bases nitrogenadas do DNA. ${ }^{42,43-48}$

Os biossensores são dispositivos simples, porém rápidos e precisos, dotados de um componente biológico - geralmente uma enzima - reconhecedor de íons ou moléculas através de reações químicas. Cada tipo de biossensor reconhece uma espécie química, permitindo afirmar se a substância em questão está presente ou não e qual a sua concentração. O sensor baseia-se na imobilização de oligonucleotídeos e emprega métodos eletroquímicos altamente sensíveis (voltametria cíclica, de pulso diferencial, de onda quadrada etc). ${ }^{42,44,45}$ Quando as interações do agente em estudo com a macromolécula de DNA não são específicas, é preferível empregar os termos eletrodos modificados de $d s$ DNA ou $s s$ DNA.

O eletrodo modificado de $d s$ DNA é uma ferramenta valiosa na observação qualitativa da interação DNA/fármacos e compostos tóxicos. Nossos estudos eletroquímicos com os compostos biscatiônicos bis-S-tioureído foram realizados em eletrodo modificado de $d s$ DNA, com o intuito de avaliar a diferença de comportamento 
entre os derivados S-tioureído contendo o grupo sulfeto (2), bioisostericamente modificado para N-Me (3), e o correspondente di-haleto do S-tioureído (1). Um estudo preliminar do composto 2, no meio trabalhado $(\mathrm{pH}=4,5)$ apresentou um pico de oxidação em $\mathrm{Ep}=0,989$ $\mathrm{V}$ vs. $\mathrm{Ag} / \mathrm{AgCl}, \mathrm{Cl}^{-} 0,1 \mathrm{~mol} \mathrm{~L}^{-1}$ e eletrodo de carbono vítreo, enquanto o eletrodo modificado de $d s$ DNA (fita dupla) é caracterizado pela ausência de picos de oxidação, devido às bases estarem protegidas por ligações de hidrogênio, dificultando a sua oxidação. Quando o eletrodo modificado foi colocado no eletrólito de suporte contendo o derivado S-tioureído 2 , pôde-se perceber, após 24 h de contato, que o pico de oxidação foi deslocado para valores de potencial menos positivos $(\mathrm{Ep}=0,880 \mathrm{~V}$ ) (Figura 5). Esse resultado demonstra que o DNA não sofreu qualquer degradação, mas, que ocorreu interação com o DNA, provavelmente eletrostática, pela atração entre os grupos fosfatos do DNA negativamente carregados e os grupos catiônicos dos grupos S-tioureído de $\mathbf{2}$.

$\mathrm{O}$ derivado 3 apresentou inicialmente no meio trabalhado $(\mathrm{pH}=$ 4,5 ) um pico de oxidação em $\mathrm{Ep}=1,234 \mathrm{~V}$ vs. $\mathrm{Ag} / \mathrm{AgCl}, \mathrm{Cl}^{-}$0,1 $\mathrm{mol}$ $\mathrm{L}^{-1}$, em eletrodo de carbono vítreo. Quando o eletrodo modificado

a)

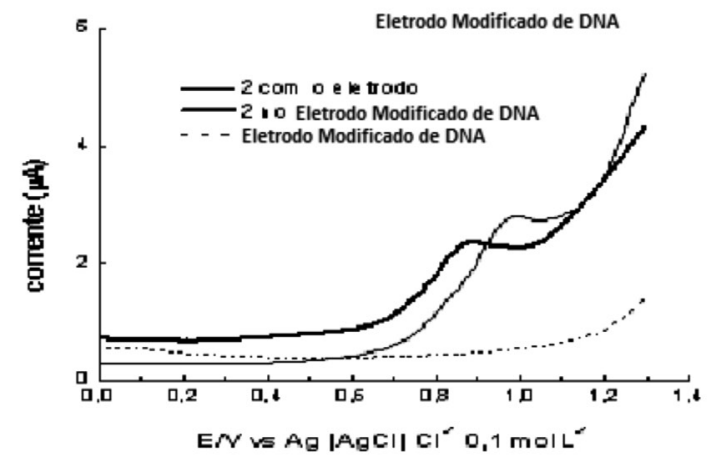

b)
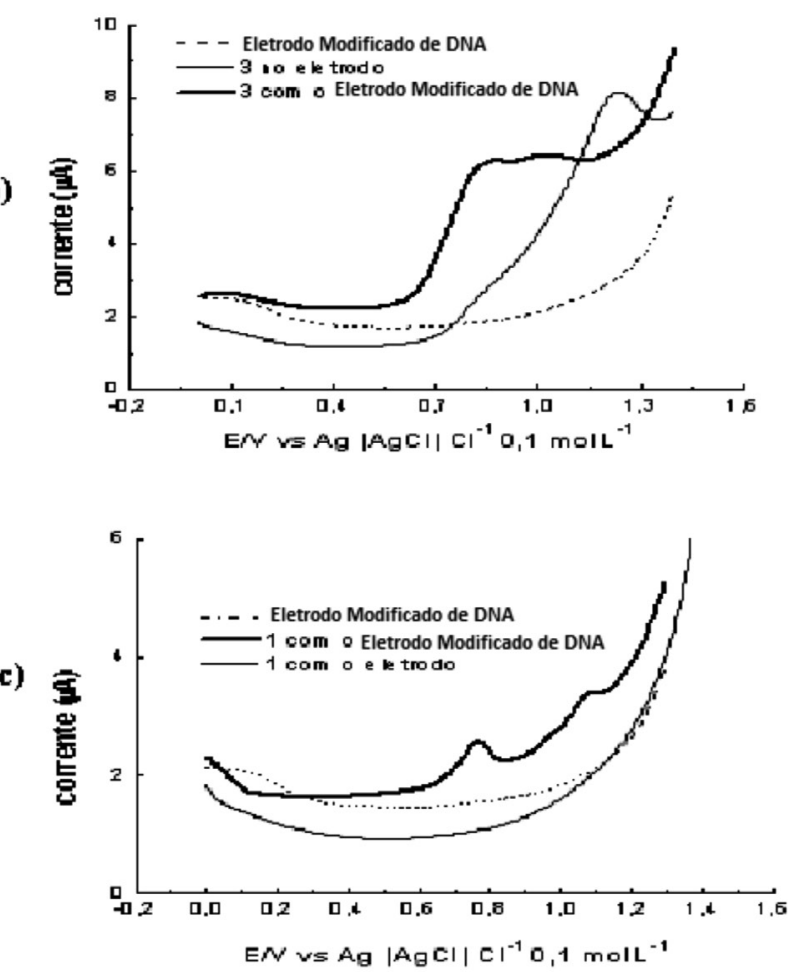

Figura 5. VPD do estudo da interação do eletrodo modificado de dsDNA em eletrodo de carbono vítreo com: a) bis-S-tioureido-sulfeto 2 ; b) bis-S-tioureido-N-metil-amino 3 ; c) di-haleto-sulfeto $1 . v=0,010 \mathrm{~V} \mathrm{~s}^{-1}$ foi imerso no eletrólito de suporte contendo 3, observou-se após 24 h de contato, Figura 5, uma mudança do comportamento voltamétrico. Houve o aparecimento do sinal de oxidação das nucleobases guanina $(\approx 0,8 \mathrm{~V})$ e adenina $(\approx 1,0 \mathrm{~V})$, devido à interação com o derivado amidínico 3 , e dois picos de oxidação do próprio derivado amidínico. Isto demonstra que 3 interage com o $d s \mathrm{DNA}$, promovendo uma mudança conformacional da fita dupla com maior exposição das bases, que podem ser mais facilmente oxidadas na superfície do eletrodo. Estudou-se, também, o comportamento do correspondente tio-di-haleto 1 frente ao DNA, utilizando-se o eletrodo modificado. Observou-se que o derivado di-haleto 1 nas mesmas condições ( $\mathrm{pH}$ $=4,5$, eletrodo de referência $\mathrm{Ag} / \mathrm{AgCl}, \mathrm{Cl}^{-} 0,1 \mathrm{~mol} \mathrm{~L}^{-1}$ e eletrodo de carbono vítreo) não apresentou qualquer pico de oxidação. Após 24 $\mathrm{h}$ de contato do di-haleto $\mathbf{1}$ com o eletrodo modificado de $d s \mathrm{DNA}$, pôde-se perceber o aparecimento de picos de oxidação nos potenciais: $+0,765$ e $+1,076 \mathrm{~V}$ (Figura 5). Esses picos são característicos da oxidação das nucleobases guanina $(\approx 0,8 \mathrm{~V})$ e adenina $(\approx 1,0 \mathrm{~V})$, respectivamente, o que demonstra que 1 interage com a molécula do DNA, provocando mudança conformacional do $d s$ DNA e/ou abertura das fitas. Como esperado o composto $\mathbf{1}$, um di-haleto de alquila, revela-se mais eletrofílico.

\section{CONCLUSÕES}

Os dois compostos planejados, derivados bis-S-tioureído substituídos 2 e 3, como novos potenciais agentes antineoplásicos, apresentam interação eletrostática com o DNA mas, de acordo com os resultados obtidos com a técnica de ITC, a interação é mais eficiente com o derivado N-metilamino-bis-tioureído 3. Isto deve ocorrer, provavelmente, pelo fato de que no composto 3 há menor distância entre os grupos biscatiônicos S-tioureídos responsáveis pela interação eletrostática com o DNA, levando a uma interação mais eficiente, como na mecloretamina. A técnica de calorimetria diferencial de varredura (DSC) foi utilizada na investigação preliminar da possível interação dos compostos sintetizados com o DNA e para confirmar que a interação com o DNA mais forte é a do di-haleto $\mathbf{1}$, mas que os derivados biscatiônicos $\mathbf{2}$ e $\mathbf{3}$ apresentam interações com o DNA comparáveis (sulfeto 2 ) ao composto conhecido como padrão, o Berenil, ou ainda melhores que o padrão (derivado amino 3). A metodologia de titulação calorimétrica isotérmica (ITC) mostrou-se confiável e reprodutível para a avaliação da interação efetiva com o DNA e a técnica de eletrodo modificado/biossensor de DNA foi importante e complementar, permitindo, com isto, uma compreensão mais ampla e profunda do mecanismo de interação com o DNA. Pode-se concluir também que os novos derivados biscatiônicos- $\alpha, \omega$-funcionalizados por grupos S-tioureídos $\mathbf{2}$ (sulfeto) e $\mathbf{3}$ (N-metilamino) apresentam interações eletrostáticas com o DNA e que o derivado di-haleto $\mathbf{1}$ apresenta interação eletrofílica com o DNA, um agente alquilante que deve provocar a degradação do DNA. Desta forma, comprovou-se a grande potencialidade e possível aplicação farmacológica dos compostos biscatiônicos, em especial do derivado $\mathbf{3}$, análogo da mecloretamina, como novos agentes antineoplásicos. Estudos complementares da atividade antineoplásica vêm sendo feitos e os resultados promissores levaram ao patenteamento de todos estes compostos. ${ }^{49}$

\section{MATERIAL SUPLEMENTAR}

As Figuras 1S a 3S estão disponíveis em http://quimicanova.sbq. org.br, na forma de arquivo PDF, com acesso livre.

\section{AGRADECIMENTOS}

Ao Conselho Nacional de Desenvolvimento Cientifico e 
Tecnológico (CNPq) e à Fundação de Amparo à Pesquisa do Estado de Minas Gerais (FAPEMIG) (PRONEX EDT479/07, PPM III 0207/09 e PPM V 0356/11) pelo apoio financeiro.

\section{REFERENCIAS}

1. Brasil, Ministério da Saúde; Mensagem aos médicos. Câncer Fundamentos, Secretária de Assistência Médica - Divisão Nacional de Câncer: Brasília, 1971, p. 7-47; http://www.inca.gov.br/releases/ press_release_view.asp?ID=2282, acessada em Maio 2012.

2. http://www1.inca.gov.br/inca/Arquivos/consenso_nutricao_vol2.pdf, acessada em Maio 2012.

3. Almeida, V. L.; Leitão, A.; Reina, L. D. C. B.; Montanari, C. A.; Donnici, C. L.; Quim. Nova 2005, 28, 118.

4. Rothschild, B. M.; Witzke, B. J.; Hershkovitz, I.; Lancet 1999, 1, 354; Natarajan, L. C.; Melott, A. L.; Rothschild, B. M.; Martin, L. D.; Quant. Biology 2007, 4, 115.

5. David, A. R.; Zimmerman, M. R.; Nat. Rev. Cancer 2010, 10, 728.

6. Duval, P. A.; Vargas, B. L.; Fripp, J. C.; Arrieira, I. C. O.; Lazzeri, B.; Destri, K.; Assunção, M. C. F.; Rev. Bras. Cancerol. 2010, 56, 207.

7. http://www.who.int/mediacentre/events/annual/world_cancer_day/en/ index.html, acessada em Janeiro 2011.

8. Castro, R.; Rev. Bras. Cancerol. 2009, 55, 41.

9. Spence, R. A. J.; Jonhston, P. G. Em Oncology; Jonhston, P. G., ed.; Oxford University Press: Oxford, 2001.

10. Murad, A. M.; Katz, A.; Oncologia Bases Clínicas do Tratamento, Guanabara: Rio de Janeiro, 1996, p. 41.

11. Salmon, S. E. Em Farmacología Básica \& Clínica; Katzung, B. G., ed.; Guanabara Koogan S. A.: Rio de Janeiro, 1998, p. 629-655.

12. Foye, W. O.; Sengupta, S. K. Em Principles of Medicinal Chemistry; Foye, W. O.; Lemke, T. L.; Williams, D. A., eds.; Williams \& Wilkins: Baltimore, 1996, p. 822-845.

13. Silverman, R. B.; The Organic Chemistry of Drug Design and Drug Action, Academic Press Inc: San Diego, 1992, caps. 3, 4, 6, 7.

14. Hurley, L. H.; Nat. Rev. Cancer 2002, 2, 188.

15. Rajski, S. R.; Williams, R. M.; Chem. Rev. 1998, 98, 2723.

16. Gilman, A.; Phillips, F. S.; Science 1946, 103, 409; Haskel, C. M.; Cancer Treatment, Saunders: Philadelphia, 1990.

17. Cohen, G. M.; Cullis, P. M.; Harltey, J. A.; Mather, A.; Symons, M. C. R.; Wheelhouse, R. T.; J. Chem. Soc., Chem. Commun. 1992, 1, 298; Holley, J. P.; Mather, A.; Wheelhouse, R. T.; Cullis, P. M.; Hartley, J. A.; Bingham, J. P.; Cohen, G. M.; Cancer Res. 1992, 52, 4190.

18. Stark, P. A.; Thrall, B. D.; Meadows, G. G.; Monem, M. M. A.; J. Med. Chem. 1992, 35, 4264.

19. Prakash, A. S.; Denny, W. A.; Gourdie, T. A.; Value, K. K.; Woodgate, P. D.; Wakelin, L. P. G.; Biochemistry 1990, 29, 9799.

20. Goodsell, D.; Dickerson, R. E.; J. Med. Chem. 1986, 29, 727.

21. Schmitz, H.; Hubner, W.; Biophys. Chem. 1993, 48, 61; Pilch, D. S.; Kirolos, M. A.; Liu, X.; Plum, G. E.; Breslauer, K. J.; Biochemistry 1995, 34, 9962.

22. Kraut, E. H.; Masspeis, L.; Bakerzark, S.; Grever, M.; Proc. Am. Soc. Clin. Oncol. 1988, 7, 62; Lombardy, R. L.; Tanious, F. A.; Ramachandran, K.; Tidewell, R. R.; Wilson, W. D.; J. Med. Chem. 1996, 39, 1453.
23. Cai, X.; Gray, P. J.; von Hoff, D. D.; Cancer Treat. Rev. 2009, 35, 437.

24. Kopka, M. L.; Yoon, C.; Goodsell, D.; Pjura, P.; Dickerson, R. E.; J. Mol. Biol. 1985, 183, 553; Marky, L. A.; Curry, J.; Breslauer, K. J.; Molecular basis of Cancer, Part B, Alan R. Liss: New York, 1985; Berman, H. M.; Olson, W. K.; Beveridge, D. L.; Westbrook, J.; Gelbin, A.; Demeny, T.; Hsieh, S. H.; Srinivasan, A. R.; Schneider, B.; Biophys. J. 1992, 63, 751.

25. Henderson, D.; Hurley, L. H.; Nat. Med. 1995, 6, 525; Neidle, S.; Nat. Prod. Rep. 2001, 18, 291; Bischoff, G.; Hoffmann, G. S.; Curr. Med. Chem. 2002, 9, 321.

26. Fujihara, H.; Imaoka, K.; Furukawa, N.; Oae, S.; J. Chem Soc. Perkin Trans. 1 1986, 465.

27. Frieba, M.; Mahmood, A.; Spies, H.; Berger, R.; Johannsen, B.; Mohammed, A.; Eisenhut, M.; Bolzati, C.; Davison, A.; Jones, A.; J. Med. Chem. 2000, 43, 2745.

28. Hardling, S. E.; Chowdhry, B. Z.; Protein-Ligand Interactions: hydrodinamics and calorimetry, Oxford University Press: Londres, 2001.

29. Feig, A. L.; Biopolymers 2007, 5, 293; Biswas, T.; Tsodikov, O. V.; Anal. Biochem. 2010, 406, 91.

30. Rickert, M.; Boulanger, M. J.; Goriatcheva, N.; J. Mol. Biol. 2004, 339, 1115 .

31. Turnbull, W. B.; Daranas, A. H.; J. Am. Chem. Soc. 2003, 125, 14859.

32. Fernandes, V. C.; Denadai, A. M. L.; Millan, R. D. S.; Alves, R. J.; Junior, A. S. C.; Braz. J. Pharm. Sci. 2007, 43, 543.

33. Jiang, W.; Nowosinski, K.; Low, N.L.; Dzyuba, E. V.; Klautzsch, F.; Schafer, A.; Huuskonen, J.; Rissanen, K.; Schalley, C.; J. Am. Chem. Soc. 2012, 134, 1860.

34. Brown, A.; Int. J. Mol. Sci. 2009, 10, 3457.

35. Salim, N. N.; Feig, A. L.; Methods 2009, 47, 198.

36. Daumantas, M.; Rouzinaa, I; Bloomfield, V. A.; J. Mol. Biol. 2000, 296, 1053.

37. Kopka, M. L.; Yoon, C.; Goodsell, D.; Pjura, P.; Dickerson, R. E.; J. Mol. Biol. 1985, 183, 553.

38. Henderson, D.; Hurley, L. H.; Nat. Med. 1995, 6, 525.

39. Montanari, C. A.; Trent, J. O.; Jenkins, T. C.; J. Braz. Chem. Soc. 1998, 9,175 .

40. Matesoi, D.; Kittler, L.; Bell, A.; Unger, E.; Lober, G.; Biochem. Mol. Biol. Int. 1996, 36, 123.

41. Millan, K. M.; Mikkelsen, S. R.; Anal. Chem. 1993, 65, 2317.

42. Mascini, M.; Palchetti, I.; Marrazza, G.; Fresenius J. Anal. Chem. 2001, 369, 15; Hillard, E. A.; Abreu, F. C.; Ferreira, D. C. M.; Jaouen, G.; Goulart, M. O. F.; Amatore, C.; Chem. Commun. 2008, 23, 2612.

43. Kerman, K.; Kobayashi, M.; Tamiya, E.; Meas. Sci. Technol. 2004, 15, R1.

44. Fan, H.; Ju, P.; Ai, S.; Sens. Actuators, B 2010, 149, 98.

45. Wang, J.; Nucleic Acids Res. 2000, 28, 3011.

46. Marrazza, G.; Chiti, G.; Mascini, M.; Anichini, M.; Clin. Chem. 2000, 46,31 .

47. Kim, E.; Lee, M.; Gatton, T. M.; Lee, J.; Zang, Y.; Sensors 2010, 10, 330.

48. Tichoniuk, M.; Ligaj, M.; Filipiak, M.; Sensors 2008, 8, 2118.

49. Donnici, C. L.; Resende, M. A.; Lopes, M. T. P.; Oliveira, S. R. O.; Nogueira, L. J.; Silva, L. L.; Montanari, C. A.; Br PI 1.410.000.457-9, 2010. 


\section{INVESTIGAÇÃO ELETROQUÍMICA E CALORIMÉTRICA DA INTERAÇÃO DE NOVOS AGENTES ANTITUMORAIS BISCATIÔNICOS COM DNA}

\section{Láuris Lucia da Silva, Claudio Luis Donnici* e Júlio César Dias Lopes}

Departamento de Química, Instituto de Ciências Exatas, Universidade Federal de Minas Gerais, Av. Antônio Carlos, 6627, $31270-$ 901 Belo Horizonte - MG, Brasil

\section{Marília Oliveira Fonseca Goulart, Fabiane Caxico de Abreu e Francine Santos de Paula}

Instituto de Química e Biotecnologia, Universidade Federal de Alagoas, Campus A. C. Simões, Tabuleiro do Martins, 57072-970

Maceió - AL, Brasil

\section{Carlos E. Salas Bravo e Marcelo Matos Santoro}

Departamento de Bioquímica e Imunologia, Universidade Federal de Minas Gerais, Av. Antônio Carlos, 6627, 31270-901 Belo Horizonte - MG, Brasil

Ângelo Márcio Leite Denadai

Centro Federal de Educação Tecnológica - Campus VII, Av. Amazonas 1193, 35183-006 Timóteo - MG, Brasil

Alexandre Martins Costa Santos

Departamento de Ciências Fisiológicas, Universidade Federal do Espírito Santo, Av. Marechal Campos 1468, 29043-900 Vitória - ES, Brasil

Carlos Alberto Montanari

Instituto de Química de São Carlos, Universidade de São Paulo, CP 780, 13560-970 São Carlos - SP, Brasil

a)<smiles>NCCCCN(CCCCN)CCCCNC(=O)Cc1ccc(N(CCCl)CCCl)cc1</smiles><smiles>NCCCCN(CCCCN)CCCCNC(=O)Cc1ccc(N(CCCl)CCCl)cc1</smiles>

b)<smiles>ClCCN(CCCl)c1ccc(CNc2c3ccccc3cc3ccccc23)cc1</smiles><smiles></smiles>

Figura 1S. Estruturas de mostardas nitrogenadas mistas: a) tipo espermidina-clorambucil; b) intercalante-clorambucil 
<smiles>C[15N]1CCN(c2ccc3nc(-c4cccc5[nH]c(-c6ccc(O)cc6)nc45)[nH]c3c2)CC1</smiles><smiles>CC1C=C(NC(=O)c2cc(NC(=O)CNC(=N)N)cn2C)C=C1C(=O)NCCC(=N)N</smiles><smiles></smiles>

Figura 2S. Estruturas do berenil, Hoechest 33258, netropsina e distamicina

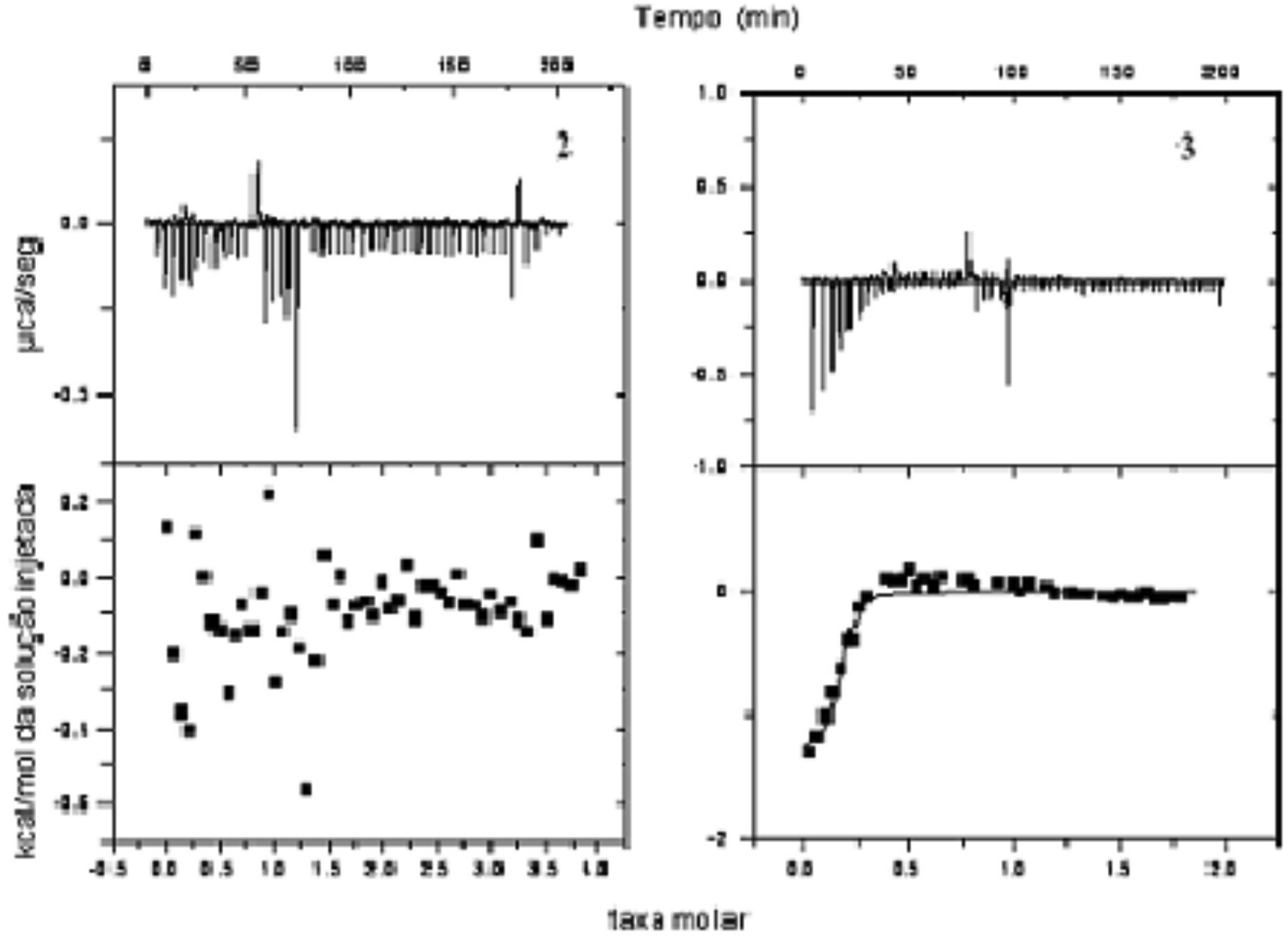

Figura 3S. Dados de ITC: titulação dos derivados amidínicos 2 e 3 com o dodecâmero do DNA; cada pico associado ao calor de injeção corresponde a uma única injeção com os calores de injeção corrigidos pela subtração das diluições; gráficos inferiores: as injeções corrigidas são analisadas junto com as taxas molares; gráficos superiores: dados experimentais dos calores de injeção 